\title{
SEROLOGICAL DETECTION OF HEPATITIS A VIRUS IN FREE-RANGING NEOTROPICAL PRIMATES (Sapajus spp., Alouatta caraya) FROM THE PARANÁ RIVER BASIN, BRAZIL
}

\author{
Walfrido Kühl SVOBODA(1), Manoel do Carmo Pereira SOARES(2), Max Moreira ALVES(2), Tatiana Carneiro ROCHA(3), Eliane Carneiro GOMES(3), \\ Fabiana MENONCIN(3), Paulo Mira BATISTA(4), Lineu Roberto da SILVA(5), Selwyn Arlington HEADLEY(6,7), Carmen Lúcia Scortecci HILST(6), \\ Lucas M. AGUIAR(1), Gabriela LUDWIG(8), Fernando de Camargo PASSOS(3), Júlio Cesar de SOUZA Jr.(9) \& Italmar Teodorico NAVARRO(6)
}

\begin{abstract}
SUMMARY
Nonhuman primates are considered as the natural hosts of Hepatitis A virus (HAV), as well as other pathogens, and can serve as natural sentinels to investigate epizootics and endemic diseases that are of public health importance. During this study, blood samples were collected from 112 Neotropical primates (NTPs) (Sapajus nigritus and S. cay, $\mathrm{n}=75$; Alouatta caraya, $\mathrm{n}=37$ ) trap-captured at the Paraná River basin, Brazil, located between the States of Paraná and Mato Grosso do Sul. Anti-HAV IgG antibodies were detected in $4.5 \%$ (5/112) of NTPs, specifically in 6.7\% (5/75) of Sapajus spp. and 0\% (0/37) of A. caraya. In addition, all samples were negative for the presence of IgM anti-HAV antibodies. These results suggest that free-ranging NTPs were exposed to HAV within the geographical regions evaluated.
\end{abstract}

KEYWORDS: Hepatitis A; New World monkeys; Zoonosis; Serology.

\section{INTRODUCTION}

Hepatitis A is an acute viral infectious disease caused by Hepatitis A virus (HAV), a single-stranded unenveloped RNA virus that is member of the genus, Hepatovirus, family Picornaviridae(1). Although HAV has one known serotype and seven genotypes, denominated I-VII ${ }^{1,2}$, recent studies have reclassified HAV into six genotypes based on the molecular analysis of the VP1 gene ${ }^{3}$. Nevertheless, genotypes I-III are more related with disease in humans ${ }^{2}$, while genotypes IV-VI are associated with simian hepatitis, and were originally identified in Old World monkeys ${ }^{4}$. Consequently, humans and nonhuman primates (NHPs) are the natural reservoirs of $\mathrm{HAV}^{1}$.

HAV-induced infection occurs primarily via the oral-fecal route due to the ingestion of contaminated food and water, or contact with infected hosts ${ }^{1,2}$. This disease is endemic in some developing countries ${ }^{4}$, including those of South America ${ }^{5}$, but particularly in regions of poor socioeconomic conditions, where adequate sanitation and hygiene practices are absent ${ }^{6}$. A serological investigation of the presence of anti-HAV antibodies in patients from different geographical regions of Brazil demonstrated an incidence of $77.2 \%(19,507 / 25,270)$, with most elevated levels occurring in northern Brazil ${ }^{7}$. However, a study conducted during an outbreak of hepatitis A in Águas Lindas de Goiás, Midwestern
Brazil, revealed an incidence of $46.4 \%(326 / 865)^{6}$; data collected from the Ministry of Health between 1999 and 2010 has demonstrated an increase in the number of cases of HAV between 1999 and 2005 in Midwestern Brazil, with a gradual decrease in the number of notifications from 2005 to 2010 , finishing with less than $5 \%$ in $2010^{8}$. Additionally, molecular analyses have demonstrated that the subgenotype IA is predominant within all geographical regions of Brazil ${ }^{5}$, suggesting that HAV is probably endemic ${ }^{9}$. Nevertheless, recent data have supported the shift of Brazil towards intermediate (North, Northeast and Central-West regions) and low (South and Southeast regions) endemicity levels of HAV, with the shift of the infection risk towards older age groups ${ }^{8,10}$.

NHPs are considered natural reservoirs of $\mathrm{HAV}^{1,3}$ and zoonotic diseases such as toxoplasmosis ${ }^{11}$ and yellow fever ${ }^{12}$, and can serve as natural sentinels for investigation of epizootics and endemic diseases of public health importance. Old World Primates are known to be very susceptible to HAV infection, with descriptions in species such as the Macaca fascicularis, Cercopithecus aethiops ${ }^{13},{\text { M. } \text { mulatta }^{14} \text {, Nomascus }}$ leucogenys, Hylobates lar, and H. pileatus ${ }^{15}$, however, reports of HAV in free-ranging Neotropical primates (NTPs) are sparse, with only one description in a collection of captive NTPs from northern Brazil ${ }^{16}$ and in several Owl monkeys (Aotus trivirgatus) from the USA ${ }^{17,18}$. There is also an experimental confirmation of HAV-induced hepatitis in the Callithrix

(1) Universidade Federal da Integração Latino-Americana (UNILA), Foz do Iguaçu, Paraná, Brasil.

(2) Instituto Evandro Chagas (IEC), Seção de Hepatologia, Ananindeua, Pará, Brasil.

(3) Universidade Federal do Paraná, Curitiba (UFPR), Paraná, Brasil.

(4) Secretaria de Estado de Saúde do Mato Grosso do Sul (SES-MS), Campo Grande, Mato Grosso do Sul, Brasil.

(5) Secretaria de Estado de Saúde do Paraná (SESA-PR), Curitiba, Paraná, Brasil.

(6) Universidade Estadual de Londrina (UEL), Departamento de Medicina Veterinária e Preventiva e Clínica de Pequenos Animais, Paraná, Brasil.

(7) Universidade de Cuiabá, Faculdade de Medicina Veterinária, Mato Grosso, Brasil.

(8) Instituto Chico Mendes de Conservação da Biodiversidade, Centro Nacional de Pesquisa e Conservação de Primatas Brasileiros (CPB), João Pessoa, Paraíba, Brasil.

(9) Universidade Regional de Blumenau, Santa Catarina, Brasil.

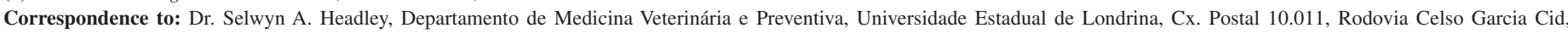
PR 445 Km 380, 86057-970, Londrina, PR, Brasil. Fone: + 5543 3371-4485. E-mail: selwyn.headley@uel.br 


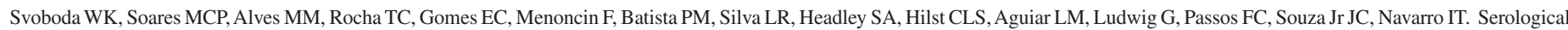
detection of hepatitis A virus in free-ranging neotropical primates (Sapajus spp., Alouatta caraya) from the Paraná River basin, Brazil. Rev Inst Med Trop Sao Paulo. 2016;58:9.

jacchus $^{19}$. Additionally, the detection of HAV in primates within Brazil is significantly reduced ${ }^{16,19}$; while descriptions of HAV in free-ranging NTPs were not located when major online databases were consulted. This report investigated the occurrence of HAV in populations of free-ranging NTPs from the Paraná River basin, southern Brazil.

\section{MATERIALS AND METHODS}

Study location: All NTPs evaluated during this study were trapcaptured as previously described ${ }^{20,21}$ within the Paraná River basin, southern Brazil, between June 2004 and April 2006. The Paraná River basin consists of several islands and riparian forest reserves that are environmentally protected by the Instituto Chico Mendes de Conservação da Biodiversidade (APA Ilhas e Varzeas do Rio Paraná; Dec s/no. September 30, 1997), in the Atlantic Forest domain, and are classified as Seasonal Semideciduous Forests. The NTPs evaluated during this study were from two forested islands (Mutum and Porto Rico) that are seasonally flooded and from forests of both riverbanks located within the outskirts of the city of Porto Rico. This city is located in the northwest of Paraná State at latitude 22 46'20"S and longitude 53॰16'01'W; divides the border with the state of Mato Grosso do Sul, and is approximately $336 \mathrm{~km}$ away from Foz do Iguaçu. Therefore, the serum samples were obtained from NTPs that resided within the states of Paraná and Mato Grosso do Sul.

Neotropical primates (NTPs): Serum samples were obtained from 112 free-ranging NTPs: Capuchin monkeys (Sapajus nigritus from the left margin of the Paraná River; $S$. cay from the right bank), $\mathrm{n}=75$; and Black-and-Gold Howler monkeys (Alouatta caraya from the two islands), $\mathrm{n}=37$. These primates lived within the forested regions of the Paraná River basin, where dense populations of NTPs are known to reside ${ }^{22}$. Permissions to capture (license № 104/04) and examine these NTPs were obtained from the Brazilian Institute of Environment and Renewable Natural Resources (Instituto Brasileiro do Meio Ambiente e dos Recursos Naturais Renováveis - IBAMA). All NTPs were anesthetized by using Zoletilß (HILST et al. unpublished data), after which blood samples were obtained by jugular venipuncture; serum was extracted and maintained at $-20{ }^{\circ} \mathrm{C}$ until used for serological assay. Biological and clinical parameters of all captured NTPs were collected (data not shown), after which all animals were released.

Serological investigation: All serum samples were evaluated by the enzyme-linked immunosorbent assay (ELISA) for the presence of total anti-HAV (Boehring Laboratory; Hessen, Germany) and anti-HAV IgM antibodies (DiaSorin; Saluggia Vercelli, Italy), using commercially available kits. The presence of anti-HAV IgG antibodies was determined by the criterion of total serum sample anti-HAV $(\operatorname{IgG}+\operatorname{IgM})$ reactive and nonreactive anti-HAV IgM antibodies. Additionally, for the presence of total anti-HAV antibodies (competitive test principle), samples whose absorbance readings yield a range of $+/-10 \%$ of the cut-off were considered negative or positive, respectively. While for the presence of anti-HAV IgM antibodies (noncompetitive test principle), samples whose assays yield absorbance readings within the range of $+/-20 \%$ of the cutoff were considered positive or negative, respectively.

Statistical analyses: Statistical analyses were performed by using the Chi-square and Fisher exact Test to establish differences between the characteristics evaluated; associations were determined by using the odds ratio $(\mathrm{OR})$ at a $95 \%$ confidence interval. A $\rho$-value of $<0.05$ was considered as statistically significant. All statistical analyses were performed by using the software Epi Info 6.0423.

Humane Care Guidelines: This study was approved by The Ethics Committee for Animal Experiments of the Universidade Estadual de Londrina (process No. 17115/2005), Paraná State, Brazil.

\section{RESULTS}

Only $4.5 \%$ (5/112) of the NTPs evaluated demonstrated positive seroreactivity to anti-HAV IgG antibodies; four of these were $S$. nigritus captured at the left bank of the Paraná River, state of Paraná, and the other was a S. cay captured at the border of Mato Grosso do Sul. Only Sapajus spp. $(6.7 \% ; 5 / 75)$ individuals reacted positively; all serum samples from A. caraya were anti-HAV negative (Table 1). Additionally, all samples evaluated were negative to anti-HAV IgM antibodies. Although no significant differences were observed when the sex $(\rho=0.67)$ and the age $(\rho=0.50)$ of the NTPs were evaluated (Table 1$)$, more adult NTPs $(5.2 \%$; $4 / 77$ ) were anti-HAV seropositive relative to their younger counterparts $(2.9 \% ; 1 / 35)$, while the rate of anti-HAV seropositivity in males $(4.5 \%$; $3 / 67)$ was similar to that found in females $(4.4 \% ; 2 / 45)$. Additionally, no significant differences were observed based on species $(\rho=0.12)$ and the states where primates were captured $(\rho=0.65)$.

\section{DISCUSSION}

The results from this study have shown that $4.5 \%$ (5/107) of the serum samples derived from free-ranging NTPs were positive for antiHAV IgG antibodies, and represent the first published investigation that evaluated the risk of NTPs being infected by HAV in Brazil. However, the results of a study that determined the occurrence of HAV in captive non-human primates (NHPs) demonstrated that $4.5 \%$ (5/125) of NHPs from the State of Rio de Janeiro and 7.6\% (17/233) of NHPs maintained within zoological parks of the State of São Paulo were seropositive for anti-HAV $\operatorname{IgG}^{24}$. These results suggest that captive and free-ranging NTPs from distinct geographical regions of Brazil were exposed to HAV.

Alternatively, elevated serum positivity was observed in a study performed in Thailand that evaluated the presence of HAV in 11 species of captive NHPs, where seroreactivity to HAV was demonstrated in $64.7 \%$ (11/17) of Macaques, $85.7 \%$ (6/7) in Langurs, and 94.6\% $(35 / 37)$ of Gibbons ${ }^{15}$. Consequently, seropositivity to HAV in captive NHPs seems to vary in different geographical locations. Additionally, SETZER $^{24}$ evaluated the presence of HAV in captive and free-ranging NHPs, and demonstrated that only captive NHPs were seropositive to IgG-anti HAV antibodies. Moreover, a recent study that evaluated the presence of zoonotic disease in captive NTPs from the state of Pará, northern Brazil, demonstrated that $12 \%$ of the 29 NTPs evaluated were seropositive for anti-HAV antibodies, but without specific reaction to IgG or IgM anti-HAV antibodies ${ }^{16}$.

In conclusion, the results of this study show the circulation of HAV in free-ranging NTPs within the Paraná River basin, Brazil. However, additional studies are required to evaluate the possible role of wildlife to act as "sentinels" for the monitoring, control, and prevention of this zoonotic disease of public health importance. 


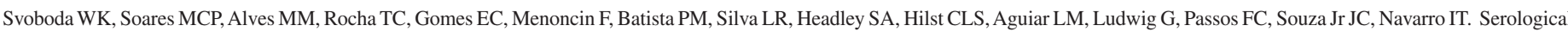
detection of hepatitis A virus in free-ranging neotropical primates (Sapajus spp., Alouatta caraya) from the Paraná River basin, Brazil. Rev Inst Med Trop Sao Paulo. 2016;58:9.

Table 1

Association between the characteristics studied (sex, age, species, and the States where primates were captured) and the presence of anti-hepatitis A virus IgG antibodies in free-ranging Neotropical primates

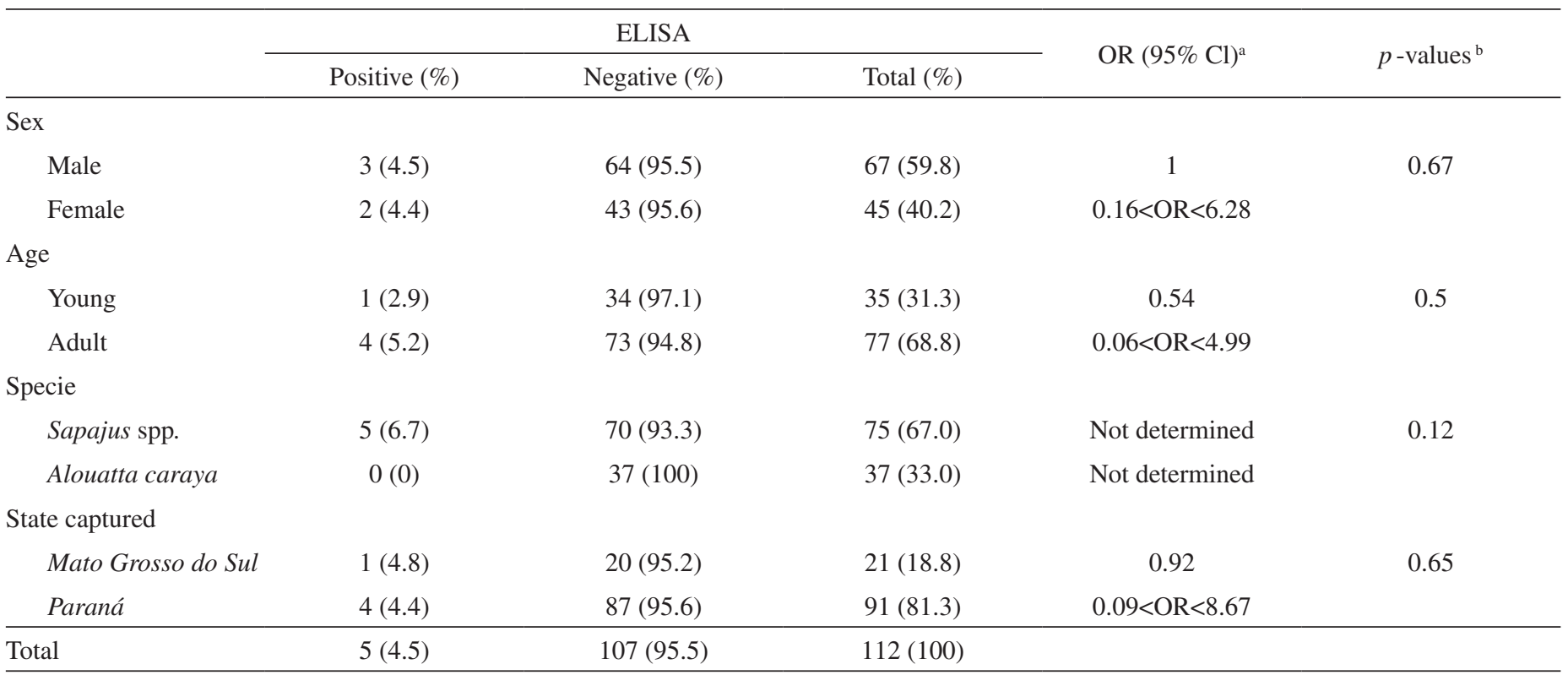

adds ratio and $95 \%$ confidence limits. ${ }^{\mathrm{b}}$ Fisher exact

\section{ACKNOWLEDGMENTS}

The authors express gratitude to the Paraná State Department of Health (SESA-PR) for the technical and logistical support during this investigation. Special mention is extended to Dr. Natal Jataí de Camargo and the entomology technicians Edílson C. Colhera, Gonçalves Beletato, José L. Filho, José P. dos Santos, Valdir O. da Silva, and Adilson Braz Secorun from the city of Porto Rico, Paraná, Brazil. Drs. Selwyn A. Headley, Fernando de Camargo Passos, and Italmar Teodorico Navarro are recipients of the National Council for Scientific and Technological Development (CNPq; Brazil) fellowships and grants.

\section{DISCLOSURE STATEMENT}

No competing financial interests exist.

\section{REFERENCES}

1. Hollinger FB, Emerson SU. Hepatitis A Virus. In: Knipe DM, Howley PM, editors. Fields Virology. 5th ed. Philadelphia: Lippincott Williams \& Wilkins; 2007. p. 911-48.

2. Yong HT, Son R. Hepatitis A virus: a general overview. Int Food Res J. 2009;16:455-67.

3. Vaughan G, Goncalves Rossi LM, Forbi JC, de Paula VS, Purdy MA, Xia G, et al. Hepatitis A virus: host interactions, molecular epidemiology and evolution. Infect Genet Evol. 2014;21:227-43

4. Robertson BH. Viral hepatitis and primates: historical and molecular analysis of human and nonhuman primate hepatitis A, B, and the GB-related viruses. J Viral Hepat. 2001;8:233-42.

5. de Paula VS, Lu L, Niel C, Gaspar AM, Robertson BH. Genetic analysis of hepatitis A virus isolates from Brazil. J Med Virol. 2004;73:378-83.
6. Andrade SSCA, Bartholomay P, Lima HCAV, Macário EM. Surto de hepatite viral tipo A no município de Águas Lindas de Goiás, em 2009. Brasília: Ministério da Saúde/ Vigilância em Saúde. Bol Eletrôn Epidemiol. 2010;10(8): 1-4.

7. Lima HCAV, Campos KB, D’Oliveira Júnior A, Knegt LV, Araújo WN. Hepatite viral tipo A: caracterização dos casos notificados pelo Sistema Nacional de Vigilância no Brasil em 2006. 8 ed. Brasília: Ministério da Saúde; 2008. Bol Eletrôn Epidemiol. 2008; 8(6):1-3.

8. Pereira GFM, Givisiez JM, Coelho RdA, Oliveira SB, Amorim TR. Bol Epidemiol Hepat Virais. 2011;2(1):82. Brasília: Ministério da Saúde; 2011.

9. Carrilho FJ, Mendes Clemente C, Silva LC. Epidemiology of hepatitis A and E virus infection in Brazil. Gastroenterol Hepatol. 2005;28:118-25.

10. Ximenes RA, Martelli CMT, Amaku M, Sartori AMC, de Soárez PC, Novaes HMD, et al. Modelling the force of infection for hepatitis A in an urban population-based survey: a comparison of transmission patterns in Brazilian macro-regions. PLoS ONE. 2014;9:e94622.

11. Garcia JL, Svoboda WK, Chryssafidis AL, de Souza Malanski L, Shiozawa MM, de Moraes Aguiar L, et al. Sero-epidemiological survey for toxoplasmosis in wild New World monkeys (Cebus spp.; Alouatta caraya) at the Parana river basin, Parana State, Brazil. Vet Parasitol. 2005;133:307-11.

12. de Almeida MA, Dos Santos E, da Cruz Cardoso J, da Fonseca DF, Noll CA, Silveira VR, et al. Yellow fever outbreak affecting Alouatta populations in southern Brazil (Rio Grande do Sul State), 2008-2009. Am J Primatol. 2012;74:68-76.

13. Tsarev SA, Emerson SU, Balayan MS, Ticehurst J, Purcell RH. Simian hepatitis A virus (HAV) strain AGM-27: comparison of genome structure and growth in cell culture with other HAV strains. J Gen Virol. 1991;72:1677-83.

14. Arankalle V, Ramakrishnan J. Simian hepatitis A virus derived from a captive rhesus monkey in India is similar to the strain isolated from wild African green monkeys in Kenya. J Viral Hepat. 2009;16:214-8. 
Svoboda WK, Soares MCP, Alves MM, Rocha TC, Gomes EC, Menoncin F, Batista PM, Silva LR, Headley SA, Hilst CLS, Aguiar LM, Ludwig G, Passos FC, Souza Jr JC, Navarro IT. Serological detection of hepatitis A virus in free-ranging neotropical primates (Sapajus spp., Alouatta caraya) from the Paraná River basin, Brazil. Rev Inst Med Trop Sao Paulo. 2016;58:9.

15. Sa-nguanmoo P, Thawornsuk N, Rianthavorn P, Sommanustweechai A, Ratanakorn P, Poovorawan Y. High prevalence of antibodies against hepatitis A virus among captive nonhuman primates. Primates. 2010;51:167-70.

16. Pereira WLA, Galo KR, Silva KSMd, Soares MdCP, Alves MM. Viral hepatitis, helminthiasis and protozoan disease in neotropical primates raised in captivity: potentially zoonotic affections with fecal-oral transmission. Rev Pan-Amaz Saude. 2010;1:57-60.

17. LeDuc JW, Lemon SM, Keenan CM, Graham RR, Marchwicki RH, Binn LN. Experimental infection of the New World owl monkey (Aotus trivirgatus) with hepatitis A virus. Infect Immun. 1983;40:766-72.

18. Lemon S, LeDuc J, Binn L, Escajadillo A, Ishak KG. Transmission of hepatitis A virus among recently captured Panamanian owl monkeys. J Med Virol. 1982;10:25-36.

19. Pinto MA, Marchevsky RS, Baptista ML, de Lima MA, Pelajo-Machado M, Vitral CL, et al. Experimental hepatitis A virus (HAV) infection in Callithrix jacchus: early detection of HAV antigen and viral fate. Exp Toxicol Pathol. 2002;53:413-20.
20. Aguiar LM, Ludwig G, Svoboda WK, Teixeira GM, Hilst CL, Shiozawa MM, et al. Use of traps to capture Black and Gold Howlers (Alouatta caraya) on the Islands of the upper Parana River, southern Brazil. Am J Primatol. 2007;69:241-7.

21. Rocha VJ, Aguiar LM, Ludwig G, Hilst CLS, Teixeira GM, Svoboda WK, et al. Techniques and trap models for capturing wild Tufted Capuchins. Int J Primatol. 2007;28:231-43.

22. Aguiar LM, Ludwig G, Roper JJ, Svoboda WK, Navarro IT, Passos FC. Howler and Capuchin monkey densities in Riparian forests on islands and adjacent shores on the upper Paraná River, southern Brazil. Neotrop Primates. 2011;18:39-43.

23. Dean AG, Dean JA, Coulombier D, Burton AH, Brendel KA, Smith DC, et al. Epi Info, version $6:$ a word processing, database, and statistics program for public health on IBM-compatible microcomputers. Atlanta: Centers for Disease Control and Prevention; 1996.

24. Setzer AP. Contribuições ao estudo da hepatite A em primatas neotropicais. São Paulo: Universidade de São Paulo; 2003.

Received:11 July 2014

Accepted: 18 May 2015 